\title{
Comparative Transcriptomic Analysis of Two Bottle Gourd Accessions Differing in Fruit Size
}

\author{
Hongyuan Zhang, Jie Tan, Min Zhang, Shuping Huang and Xia Chen * \\ Wuhan Academy of Agricultural Sciences, Wuhan 430070, China; hongyuanzhang2011@163.com (H.Z.); \\ aggas@126.com (J.T.); zhangmin818@aliyun.com (M.Z.); hsping80@163.com (S.H.) \\ * Correspondence: chenxia_001@126.com
}

Received: 27 February 2020; Accepted: 26 March 2020; Published: 27 March 2020

\begin{abstract}
The bottle gourd (Lagenaria siceraria) is an important horticultural and medicinal crop with high nutritional value. This study aimed at examining the molecular regulation of fruit size in bottle gourd. We performed transcriptome sequencing of two bottle gourd cultivars differing in their fruit size. The average fruit length and weight of the cultivar Hang $(39.48 \mathrm{~cm} / 624.4 \mathrm{~g})$ were higher than those of the cultivar USA $(10.34 \mathrm{~cm} / 152.8 \mathrm{~g})$ at maturity. Transcriptome sequencing and assembly resulted in 89,347 unigenes. A total of 1250 differentially expressed genes (DEG) were found between the two cultivars, including 422 upregulated genes and 828 downregulated genes in Hang as compared to USA. Genes related to cell wall metabolism, phytohormones, cell cycle, and cell division showed significant differential expression between the two cultivars. DEGs encoding transcription factors (TF) from nine TF families were also identified. The ethylene response factor family was the most enriched among these families. Our study provides a basis for further investigations of the molecular regulation of fruit size in bottle gourd.
\end{abstract}

Keywords: Lagenaria siceraria; candidate genes; fruit size; transcription factors; gene expression

\section{Introduction}

The bottle gourd (Lagenaria siceraria, $2 \mathrm{n}=2 \times=22$ ), a member of the Cucurbitaceae family [1], is an important horticultural and medicinal crop [2]. It originated in Africa and was independently domesticated in Africa and Asia [3]. The fruit of bottle gourd can be used as vegetable, utensil, ornamental, and even as a musical instrument. The bottle gourd is a great source of essential nutrients, such as vitamin B complex, pectin, fibers, ascorbic acid, beta-carotene, protein, amino acids, and minerals [4].

Bottle gourd fruit varies in shape and size [5,6]. Various genetic components are involved in determining fruit size and shape during fruit development [7]. Fruit development in fleshy fruits can generally be divided into two stages, i.e., early fruit development and fruit ripening. Early fruit development involves (i) fruit setting, (ii) fruit growth by cell division, and (iii) fruit growth by cell expansion until it reaches its final size and shape [8]. Rapid cell division and cell elongation occur during the growth stage and determine the final size and shape of the fruit [9]. Fruit size and shape are among the most important characters of any fruit which determine its market value. Optimization of desired shape and size of the fruit demands extensive investigation of molecular mechanisms regulating fruit development.

The plant cell wall is mainly composed of polysaccharides. Hundreds of genes are involved in cell wall metabolism [10]. Regulation of cell wall biogenesis and modification plays an important role in cell expansion and unidirectional elongation during fruit development [11,12]. Expansins are some of the most well characterized cell wall proteins that regulate cell size and growth during all plant growth stages and fruit development [13]. Previous studies showed that expansins are abundantly expressed during fruit development and ripening [14]. The cell cycle regulation is of key importance 
for plant growth and development. Cell division and expansion are controlled by various factors. Cyclins and cyclin-dependent protein kinases are the main regulators of the cell cycle [15]. Many studies have shown an increase in cyclins' expression during early fruit development in tomato and cucumber $[14,16,17]$.

Hormones also contribute to regulating fruit development and size [18]. The seeds are rich in auxin and cytokinin, which are the main regulators of fruit development and also determine the fruit size. An increase in auxin and cytokinin levels in seeds is correlated with fruit growth stages [19]. The role of auxin in cell expansion during fruit development stages is well established [20,21]. Numerous studies have demonstrated the role of auxin response factors (ARFs), the main regulators of auxin, in cell division and growth during fruit development [20-24]. Transcription factors also regulate genes related to fruit development $[8,25,26]$.

Recently, transcriptomic sequencing has been used to study the molecular basis of fruit development in many fleshy fruits, including cucumber, melon, and tomato [14,27-31]. However, most of the studies focused on fruit ripening and quality, and very few specifically investigated genes related to fruit size, at least in Cucurbitaceae species. Qi et al. [32] identified a candidate gene that encodes cyclins controlling cell proliferation and fruit size in cucumber and C. sativus. Jiang et al. [15] also highlighted the important role of microtubules and cyclins-related genes in determining cucumber fruit size. Later on, Wang et al. [33] pinpointed the key role of auxin and cytokinin signaling in fruit length of cucumber. All these previous studies suggest that phytohormones, cell wall metabolism, and cell cycle and cell division are the key pathways for fruit size determination in Cucurbitaceae.

In the present study, we investigated the transcriptome of two cultivars of bottle gourd (USA and Hang) with contrasting fruit size. Our goal was to identify key pathways, structural genes, and regulators involved in the differential fruit size. It is anticipated that the information generated in this work will be helpful for bottle gourd breeding programs aimed at developing cultivars with improved fruit size.

\section{Materials and Methods}

\subsection{Plant Materials}

Two cultivars of bottle gourd (Lagenaria siceraria, $2 n=2 x=22 \mathrm{cv}$. Hang and USA) were used in this study. These commercial cultivars are highly grown and consumed in Wuhan, China. Fruit size of USA is considerably shorter than that of Hang. The plants were grown in the greenhouse of the Vegetable Institute of Wuhan Academy of Agricultural Sciences, Wuhan, China. Plants were grown in a substrate composed of vermiculite:perlite: organic fertilizer $=4: 4: 1: 1$. The $\mathrm{pH}$ of the culture substrate was about 7.0, and the water content was maintained at about $70 \%$ relative humidity. The greenhouse conditions were maintained at $25-28 / 18-20{ }^{\circ} \mathrm{C}$ day/night temperature, photoperiod $14 \mathrm{~h} / \mathrm{d}$ with a light intensity of $87.5 \mu \mathrm{mol} \mathrm{m} \mathrm{m} \mathrm{s}^{-1}$. Pest control was performed according to standard practices. Mature fruits were harvested from three individual plants of each cultivar, and $2 \mathrm{~cm}^{3}$ of the pericarp was cut, immediately frozen in liquid nitrogen, and stored at $-80^{\circ} \mathrm{C}$ until further use.

\subsection{Histological Analysis}

A scalpel was used to cut the pericarp tissue into thin slices. The slices were fixed for $12 \mathrm{~h}$ in Carnoy's fixative solution (alcohol, acetic acid; V:V 3:1), stained 2 min with $1 \%$ Janus green, and then rinsed with 70\% ethanol for $10 \mathrm{sec}$. Sections were examined using an Olympus BX-50 microscope.

\subsection{RNA Extraction and Quality Test}

Six frozen fruit samples were ground in a mortar with liquid nitrogen, and total RNA was isolated using the RNA extraction kit (Huayueyang, China). RNA degradation and contamination were monitored on $1 \%$ agarose gels. RNA purity was checked using the NanoPhotometer ${ }^{\circledR}$ spectrophotometer (IMPLEN, CA, USA). RNA integrity was assessed using the RNA Nano 6000 Assay Kit of the Agilent Bioanalyzer 2100 system (Agilent Technologies, CA, USA). 


\subsection{RNA-Seq Library Preparation and Sequencing}

A total amount of $3 \mu \mathrm{g}$ RNA per sample was used as input material for the RNA sample preparations. Sequencing libraries were generated using NEBNext ${ }^{\circledR}$ Ultra $^{\mathrm{TM}}$ RNA Library Prep Kit for Illumina ${ }^{\circledR}$ (NEB, Carlsbad, CA, USA) following the manufacturer's recommendations, and index codes were added to attribute sequences to each sample. Briefly, mRNA was purified from total RNA using poly-T oligo-attached magnetic beads. Fragmentation was carried out using divalent cations under elevated temperature in NEBNext First Strand Synthesis Reaction Buffer (5x). First strand cDNA was synthesized using random hexamer primers and M-MuLV Reverse Transcripta (RNase $\mathrm{H}^{-}$). Second strand cDNA synthesis was subsequently synthesized using DNA Polymerase I and RNase H. Remaining overhangs were converted into blunt ends via exonuclease/polymerase activities. After adenylation of the $3^{\prime}$ ends of DNA fragments, NEBNext Adaptors with a hairpin loop structure were ligated to prepare for hybridization. To select cDNA fragments of 150 200 bp in length preferentially, the library fragments were purified with AMPure XP system (Beckman Coulter, Beverly, MA, USA). Then $3 \mu$ l USER Enzyme (NEB, Carlsbad, CA, USA) was used with size-selected, adaptor-ligated cDNA at $37^{\circ} \mathrm{C}$ for $15 \mathrm{~min}$ followed by $5 \mathrm{~min}$ at $95^{\circ} \mathrm{C}$ before PCR. Then PCR was performed with Phusion High-Fidelity DNA polymerase, Universal PCR primers, and Index (X) Primer. At last, PCR products were purified (AMPure XP system), and library quality was assessed on the Agilent Bioanalyzer 2100 system. The clustering of the index-coded samples was performed on a cBot Cluster Generation System using a TruSeq PE Cluster Kit v3-cBot-HS (Illumina, San Diego, CA, USA) according to the manufacturer's instructions. After cluster generation, the library preparations were sequenced on an Illumina Hiseq 2000 platform, and paired-end reads were generated.

\subsection{Quality Control and Transcriptome Assembly}

Raw data of fastq format were first processed through in-house perl scripts. In this step, clean data were obtained by removing reads containing adapters, reads containing poly- $\mathrm{N}$, and low-quality reads from raw data. At the same time, Q20, Q30, GC-content, and sequence duplication level of the clean data were calculated. All the downstream analyses were based on clean data with high quality. Transcriptome assembly was accomplished using Trinity [34] with min_kmer_cov set to 2 by default, and all other parameters set to default.

\subsection{Quantification of Gene Expression and Differential Expression Analysis}

Gene expression levels were estimated by RSEM [35] for each sample. Clean data were mapped back onto the assembled transcriptome. The read count for each gene was obtained from the mapping results. Differential expression analysis was performed using the DESeq R package (1.10.1) [36]. $p$-value was adjusted using $q$-value [37]. $q$-value $<0.005$ and $\mid \log 2$ (fold change) $\mid>1$ was set as the threshold for significantly differential expression.

\subsection{GO and KEGG Pathway Enrichment Analysis}

Gene ontology (GO) enrichment analysis of the differentially expressed genes (DEGs) was implemented by the topGO R packages based Kolmogorov-Smirnov test. We used KOBAS [38] software to test the statistical enrichment of differential expression genes in Kyoto Encyclopedia of Genes and Genomes (KEGG) pathways.

\subsection{Validation of RNA-Seq Results by qRT-PCR}

Total RNA was extracted from the flesh of bottle gourd USA and Hang at the mature stage. RNA-free DNaseI (Fermentas, Waltham, MA, USA) was used to remove DNA contamination for $20 \mathrm{~min}$ at $37^{\circ} \mathrm{C}$. Approximately $1 \mu \mathrm{g}$ of total RNA was reverse transcribed using Oligo $(\mathrm{dT})_{18}$ and a Fermentas Revert Aid First Strand cDNA Synthesis Kit (Fermentas, Glen Burnie, MD, USA). The reactions were incubated for $30 \mathrm{~min}$ at $16^{\circ} \mathrm{C}$, followed by 60 cycles of pulsed reverse transcription at $30^{\circ} \mathrm{C}$ for $30 \mathrm{~s}$, $42{ }^{\circ} \mathrm{C}$ for $30 \mathrm{~s}$ and $50{ }^{\circ} \mathrm{C}$ for $1 \mathrm{~s}$; and finally terminated by incubating at $70{ }^{\circ} \mathrm{C}$ for $5 \mathrm{~min}$. Relative 
expression analysis of the mRNA was performed using the ABI Step One Plus ${ }^{\mathrm{TM}}$ Real Time PCR System (Applied Biosystems, Carlsbad, CA, USA) and SYBR Green Master Mix (Roche, Berlin, Germany). Quantitative real-time PCR was performed using the following parameters: $5 \mathrm{~min}$ at $95^{\circ} \mathrm{C}$, followed by 40 cycles of $15 \mathrm{~s}$ at $95^{\circ} \mathrm{C}$ and $60 \mathrm{~s}$ at $60^{\circ} \mathrm{C}$. LsH3 was chosen as the endogenous control [39]. The reactions were performed with three biological replicates, and a melting curve analysis was carried out to verify that only one specific amplification occurred. Comparative expression levels were calculated in the four different samples using the $2^{-\Delta \Delta C T}$ method. Primer sequences are provided in Table S1.

\section{Results}

\subsection{Overview of the Transcriptome Sequencing}

We performed transcriptome sequencing of two bottle gourd cultivars with varying fruit sizes (Figure 1A). Fruit length and weight were measured at the marketable mature fruit stage. The average fruit length of Hang and USA was $39.48 \pm 2.30 \mathrm{~cm}$ and $10.34 \pm 1.49 \mathrm{~cm}$, respectively. Similarly, the average fruit weight was $624.4 \pm 19.81 \mathrm{~g}$ and $152.8 \pm 10.36 \mathrm{~g}$ for Hang and USA, respectively. We further performed histological analyses of the pericarp to observe cell size and cell number. From the pictures, it was noticed that Hang cells (Figure 1B) were slightly larger than USA cells (Figure 1C), while no obvious change was observed for the cell number. We deduce that variation in cell size is the underlying reason for the difference in Hang and USA fruit sizes. Nonetheless, since our histology analysis was mainly descriptive, a new experiment based on a quantitative approach is required to assess whether there is no significant difference in cell numbers between the two cultivars.

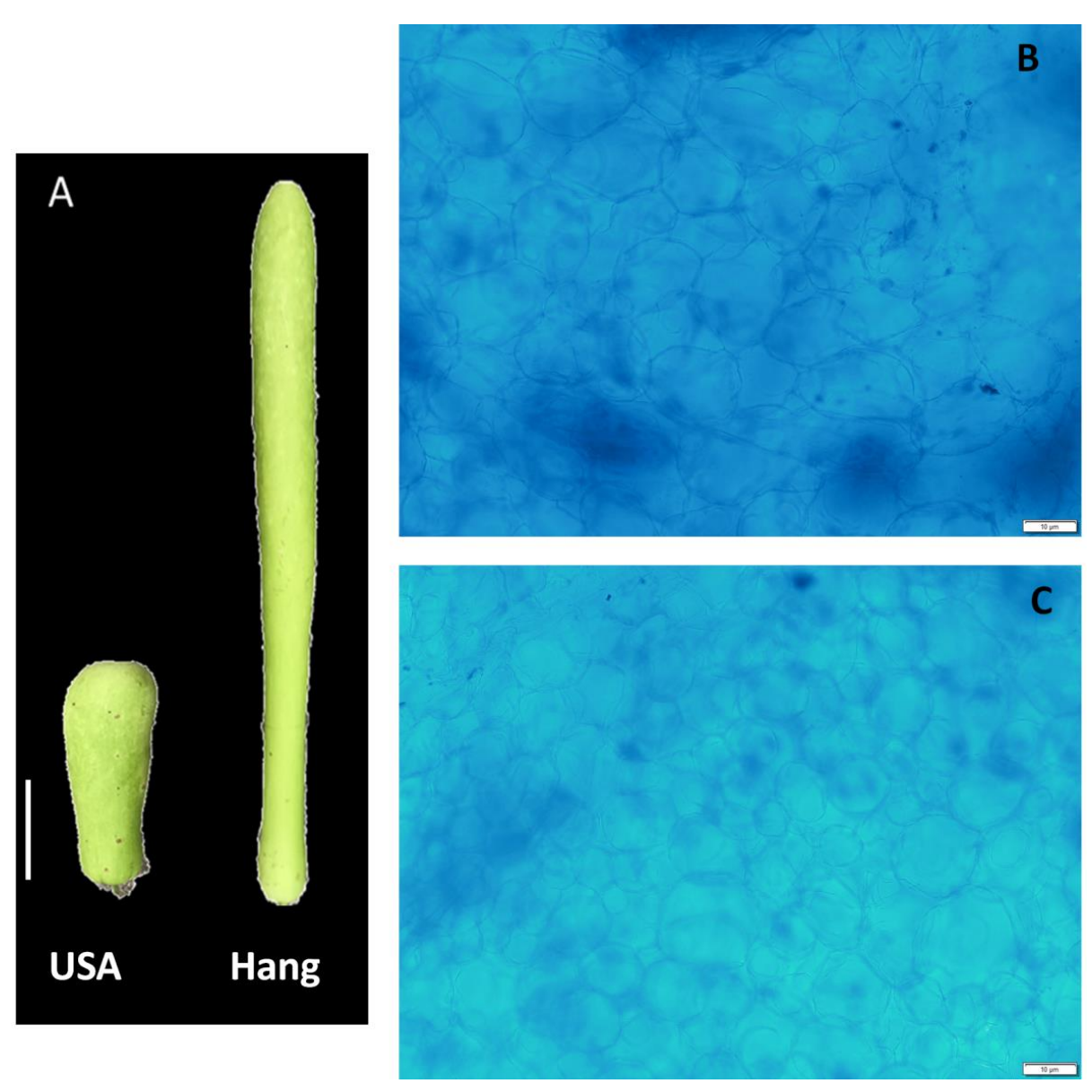

Figure 1. Phenotypes of the bottle gourd fruit Hang and USA. (A) Pictures of fruits of the two cultivars at maturity; bar $=5 \mathrm{~cm}$ (B) Histological photograph of pericarp section in Hang fruit; (C) Histological photograph of pericarp section in USA fruit; bar $=10 \mu \mathrm{m}$. 
Six sequencing libraries (three repeats for each cultivar) were constructed. After sequencing quality control, a total of 43.60 GB clean data (with an average of 7.20 GB per sample) was obtained, and the percentage of Q30 score of all products was not less than 92.52\% (Table 1). A total of 89,347 Unigenes were obtained by assembly. The N50 of Unigenes was 1318 bp, with high assembly integrity (Figure S1; Table 2).

Table 1. Sequencing data output statistics.

\begin{tabular}{ccccc}
\hline Sample & Reads Number & Base Number & GC (\%) & Q30 (\%) \\
\hline USA-1 & $24,654,704$ & $7,324,872,010$ & 46.44 & 95.05 \\
USA-2 & $20,603,617$ & $6,128,464,774$ & 47.15 & 95.07 \\
USA-3 & $22,691,144$ & $6,761,304,624$ & 47.40 & 95.06 \\
Hang-1 & $24,099,233$ & $7,170,632,760$ & 46.86 & 95.11 \\
Hang-2 & $22,126,702$ & $6,587,239,876$ & 47.56 & 95.07 \\
Hang-3 & $32,326,508$ & $9,629,968,446$ & 46.60 & 92.52 \\
\hline
\end{tabular}

Table 2. Statistics of assembly results.

\begin{tabular}{ccc}
\hline Transcripts Length (bp) & Transcripts & Unigenes \\
\hline $200-300$ & $35,479(26.00 \%)$ & $34,198(38.28 \%)$ \\
$300-500$ & $23,689(17.36 \%)$ & $20,464(22.90 \%)$ \\
$500-1000$ & $26,171(19.18 \%)$ & $16,520(18.49 \%)$ \\
$1000-2000$ & $28,275(20.72 \%)$ & $10,600(11.86 \%)$ \\
2000+ & $22,831(16.73 \%)$ & $7564(8.47 \%)$ \\
Total Number & 136,450 & 89,347 \\
Total Length (bp) & $147,822,489$ & $65,896,421$ \\
N50 Length (bp) & 1906 & 1318 \\
Mean Length (bp) & 1083 & 738 \\
\hline
\end{tabular}

\subsection{Gene Expression Analysis}

Fragments per kilobase per million mapped reads (FPKM) values were used to calculate the expression abundance of corresponding unigenes. Overview of transcriptome sequencing is shown in Figure 2. Overall, similar global gene expression could be observed among samples, and Pearson's correlations between replicates ranged from 0.842 to 0.988 (Figure 2). A total of 1250 differentially expressed genes (DEG) were found between USA and Hang. Downregulated DEGs outnumbered the upregulated genes (Figure 3; Table S2).

\subsection{Bottle Gourd Fruit Size Related DEGs}

\subsubsection{Cell Wall Metabolism}

Rapid cell elongation occurs during all plant growth stages [40]. The modification of the plant cell wall is highly required for the release of wall stress and a decrease in rigidity to allow cell elongation [12,41,42]. We identified 19 cell wall metabolism-related genes showing significant differential expression. Among these, 13 DEGs had higher expression in Hang than USA. Xyloglucans are hemicelluloses present in the cell wall and are required for cell wall organization [43]. We identified four DEGs related to xyloglucan metabolism. Two of these DEGs were upregulated in Hang. Expansins are also very important for the loosening of the cell wall to allow cell elongation and growth $[11,13]$. Four expansin genes were significantly upregulated in Hang. Endoglucanases are a fundamental part of the cell wall metabolic process $[10,44]$. Six DEGs related to endoglucanases showed significantly differential expression in fruit development. Five of them were upregulated in Hang (Table 3). 
A

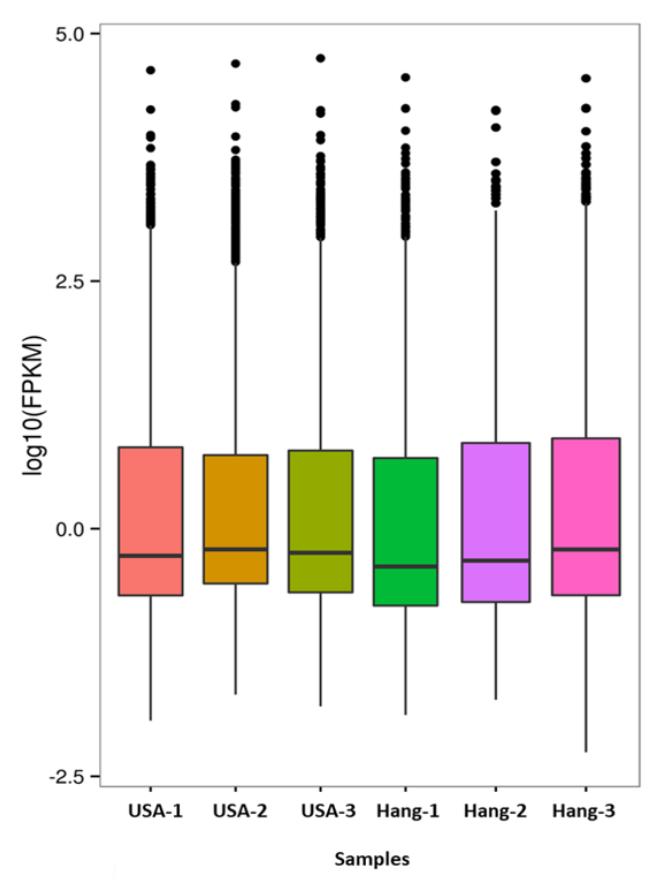

B

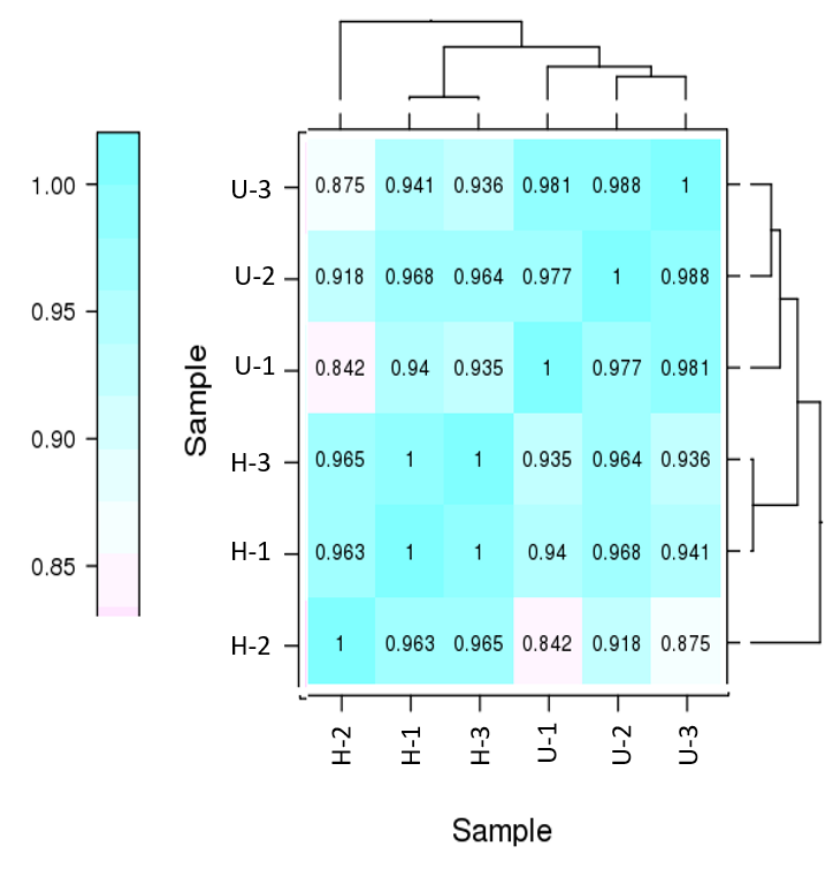

Figure 2. Overview of the transcriptome sequencing. (A) Gene expression profiles in the six libraries; (B) Heatmap clustering showing correlation among samples based on global expression profiles. U represents the USA fruit, while $\mathrm{H}$ represents the Hang fruit.

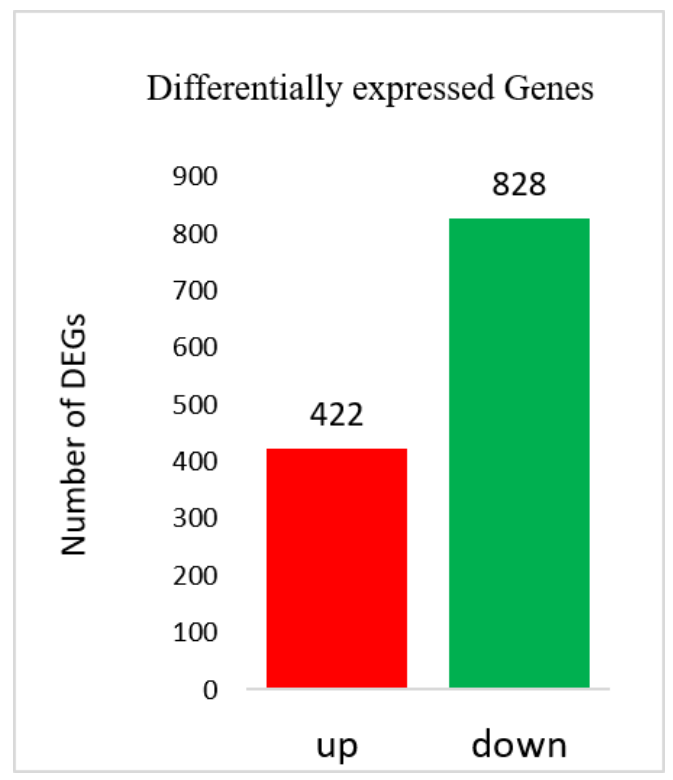

Figure 3. Differentially expressed genes (DEGs) identified between the two accessions.

Table 3. Differentially expressed genes (DEGs) related to cell wall metabolism.

\begin{tabular}{ccccc}
\hline DEGs & log2FC & Regulated & Name & Gene Annotation \\
\hline c58119.graph_c1 & -1.08 & down & CSLH1 & Cellulose synthase-like protein H1 \\
c59759.graph_c0 & -8.64 & down & EGL & Endoglucanase \\
c40345.graph_c0 & 2.11 & up & EGL11 & Endoglucanase 11 \\
c54912.graph_c1 & 1.31 & up & EGL24 & Endoglucanase 24 \\
c25441.graph_c0 & 1.39 & up & EGL6 & Endoglucanase 6 \\
c48168.graph_c0 & 1.16 & up & EGL6 & Endoglucanase 6 \\
\hline
\end{tabular}


Table 3. Cont.

\begin{tabular}{ccccc}
\hline DEGs & log2FC & Regulated & Name & Gene Annotation \\
\hline c51124.graph_c4 & 1.82 & up & EGL8 & Endoglucanase 8 \\
c35248.graph_c0 & 1.07 & up & EXPA1 & Expansin-A1 \\
c55140.graph_c2 & 1.45 & up & EXPA4 & Expansin-A4 \\
c60876.graph_c0 & 1.71 & up & EXPB3 & Expansin-B3 \\
c46611.graph_c0 & 1.10 & up & EXPB3 & Galactoside 2-alpha-L-fucosyltransferase \\
c25817.graph_c0 & 1.24 & up & GALA2 & Galacturonosyltransferase-like 2 \\
c57127.graph_c0 & 1.30 & up & GATL2 & Sucrose-phosphate synthase 4 \\
c57645.graph_c0 & -3.04 & down & SPS4 & Sucrose synthase 5 \\
c47890.graph_c0 & -1.99 & down & SUS5 & Xyloglucan endotransglucosylase/hydrolase 2 \\
c60320.graph_c1 & -8.14 & down & XTH2 & Xyloglucan endotransglucosylase/hydrolase \\
c60320.graph_c0 & -7.83 & down & XTH22 & protein 22 \\
c57140.graph_c2 & 1.66 & up & XTH8 & Xyloglucan endotransglucosylase/hydrolase \\
c58642.graph_c3 & 1.46 & up & XXT5 & Xyloglucan glycosyltransferase 5 \\
\hline
\end{tabular}

\subsubsection{Cell Cycle and Cell Division}

Regulation of cell cycle and cell division directly affects the growth rate of plant tissues and also determines the final size of plant organs $[19,40]$. We identified six DEGs involved in the regulation of cell cycle and cell division. Four of these DEGs were upregulated in Hang fruits (Table 4).

Table 4. DEGs controlling cell cycle and cell division.

\begin{tabular}{ccccc}
\hline DEGs & log2FC & Regulated & Gene & Gene Annotation \\
\hline c54419.graph_c0 & 1.28 & up & CYCD4-1 & Cyclin-D4-1 \\
c57058.graph_c0 & -1.10 & down & DCC1 & sister chromatid cohesion protein \\
c58714.graph_c1 & -1.25 & down & CLB1 & G2/mitotic-specific cyclin \\
c58562.graph_c2 & 8.28 & up & MIP1 & MND1-interacting protein 1 \\
c31188.graph_c0 & 1.93 & up & USP17L2 & Ubiquitin carboxyl-terminal hydrolase 12 \\
c50340.graph_c0 & 2.65 & up & CYCU4-1 & Cyclin-U4-1 \\
\hline
\end{tabular}

\subsubsection{Regulation of Hormones Related to Fruit Size in Bottle Gourd}

The role of plant hormones in the regulation of plant growth and fruit development is well established [18]. Auxin plays a role in cell elongation during fruit development stages [12,18]. We identified six DEGs related to auxin. Four of these were highly upregulated in Hang. Cytokinin regulates cell division during fruit development [19]. In our study, three cytokinin genes showed significant differential expression. One of these was upregulated in Hang (Table 5). Gibberellin regulates plant growth and development at various stages. We found one gibberellin 3 - $\beta$-dioxygenase 1 gene, which was downregulated in Hang fruit (Table 5).

Table 5. DEGs related to hormones involved in fruit development.

\begin{tabular}{|c|c|c|c|c|c|c|}
\hline Hormone & DEGs & $\log 2 \mathrm{FC}$ & Regulated & Gene Name & Annotation & References \\
\hline Auxin & c46159.graph_c0 & 1.29 & up & ABP20 & auxin-binding protein $\mathrm{ABP} 20$ & \\
\hline Auxin & c61117.graph_c0 & 1.07 & up & AX15A & auxin-induced protein 15A & \\
\hline Auxin & c25446.graph_c0 & 1.40 & up & $\mathrm{AX} 10 \mathrm{~A}$ & auxin-induced protein $\mathrm{X} 10 \mathrm{~A}$ & \\
\hline Auxin & c61022.graph_c0 & 1.09 & up & AX10A & auxin-induced protein $\mathrm{X} 10 \mathrm{~A}$ & \\
\hline Auxin & c60738.graph_c0 & -1.59 & down & AX17 & auxin-induced protein $\mathrm{X} 17$ & Su et al. [45] \\
\hline Auxin & c54941.graph_c0 & 1.00 & up & AFB3 & Protein auxin SIGNALING F-BOX 3 & \\
\hline Auxin & c25539.graph_c0 & -1.45 & down & PIN8 & auxin efflux carrier component 8 & \\
\hline Cytokinin & c51465.graph_c0 & -1.63 & down & CKX1 & cytokinin dehydrogenase 1 & \\
\hline Cytokinin & c54736.graph_c2 & -1.25 & down & CKX3 & cytokinin dehydrogenase 3 & $\begin{array}{c}\text { Bartrina et al. } \\
\text { [46] }\end{array}$ \\
\hline $\begin{array}{l}\text { Cytokinin } \\
\text { gibberellin }\end{array}$ & $\begin{array}{l}\text { c56658.graph_c1 } \\
\text { c54210.graph_c0 }\end{array}$ & $\begin{array}{c}1.60 \\
-2.55\end{array}$ & $\begin{array}{l}\text { up } \\
\text { down }\end{array}$ & $\begin{array}{c}\text { CKX7 } \\
\text { GA3OX1 }\end{array}$ & $\begin{array}{c}\text { cytokinin dehydrogenase } 7 \\
\text { gibberellin 3-beta-dioxygenase } 1\end{array}$ & Rieu et al. [47] \\
\hline
\end{tabular}




\subsubsection{Analysis of Homologs of Well-Known Genes Involved in Fruit Size in Bottle Gourd}

In other plants, such as tomato and Arabidopsis thaliana, some genes have been characterized, and their functions in controlling fruit size have been demonstrated. In our DEGs, we detected the gene c25755.graph_c0, which is the homolog of fruit weight 2.2 (FW2.2) from tomato [48]. The gene $c 25755$.graph_c0 was 16-fold higher expressed in USA than in Hang fruit. We also identified c52330.graph_c0 as the homolog of Cell Size Regulator (CSR) from tomato [49]. The expression level of c52330.graph_c0 was six-fold higher in Hang than USA. Furthermore, c39771.graph_c0 is the homolog of AtHXK-1 known to regulate fruit size in Arabidopsis [50]. Our data showed that c39771.graph_c0 was upregulated in USA, indicating a negative role in fruit size in bottle gourd.

\subsubsection{Transcriptional Regulation of Fruit Size in Bottle Gourd}

Transcription factors (TF) regulate gene expression during all developmental and growth stages of the plant, leaving no exception for fruit development [8]. We identified 26 DEGs from eight TF families showing significant differential expression during fruit development. The ethylene-responsive transcription factor (ERF) family had the highest number of DEGs. All of the ERFs were highly upregulated in Hang. Four members, each of WRKY and bHLH families, showed significant differential expression (Table 6).

Table 6. Transcription factors (TF) regulating fruit size.

\begin{tabular}{|c|c|c|c|}
\hline TFs & DEGs & $\log 2$ (Fold Change) & Regulation \\
\hline APRR2 & c57380.graph_c0 & 1.51 & up \\
\hline bHLH & c50592.graph_c0 & -1.04 & down \\
\hline bHLH & c51433.graph_c0 & -5.87 & down \\
\hline bHLH & c59721.graph_c1 & 1.59 & up \\
\hline bHLH & c49783.graph_c0 & 1.22 & up \\
\hline bZIP & c52788.graph_c0 & -6.03 & down \\
\hline bZIP & c49079.graph_c0 & -5.71 & down \\
\hline ERF & c60551.graph_c0 & 1.90 & up \\
\hline ERF & c26154.graph_c0 & 4.02 & up \\
\hline ERF & c56200.graph_c0 & 2.79 & up \\
\hline ERF & c38764.graph_c1 & 2.29 & up \\
\hline ERF & c48136.graph_c0 & 5.76 & up \\
\hline ERF & c41795.graph_c0 & 2.43 & up \\
\hline ERF & c38764.graph_c0 & 1.92 & up \\
\hline ERF & c48845.graph_c0 & 1.81 & up \\
\hline MYB-like & c46418.graph_c1 & -1.55 & down \\
\hline MYB-like & c60190.graph_c8 & 1.53 & up \\
\hline MYC-like & c60674.graph_c0 & 1.78 & up \\
\hline RAD & c28120.graph_c0 & -3.00 & down \\
\hline RAD & c58182.graph_c0 & -1.39 & down \\
\hline RAD & c46206.graph_c0 & -2.77 & down \\
\hline TFIIB & c53245.graph_c1 & 1.15 & up \\
\hline WRKY & c49238.graph_c0 & -4.92 & down \\
\hline WRKY & c40434.graph_c0 & -1.55 & down \\
\hline WRKY & c48149.graph_c0 & -1.57 & down \\
\hline WRKY & c54131.graph_c0 & 1.36 & up \\
\hline
\end{tabular}

\subsection{Validation of Fruit Size Related Genes by qRT-PCR}

We further performed qRT-PCR analysis to validate some candidate genes related to bottle gourd fruit size. As shown in Figure 4, there were significant differences in gene expression between the two accessions, and the trend perfectly matched observations in the RNA-seq. These results support the reliability of our RNA-seq report and subsequent interpretations. 

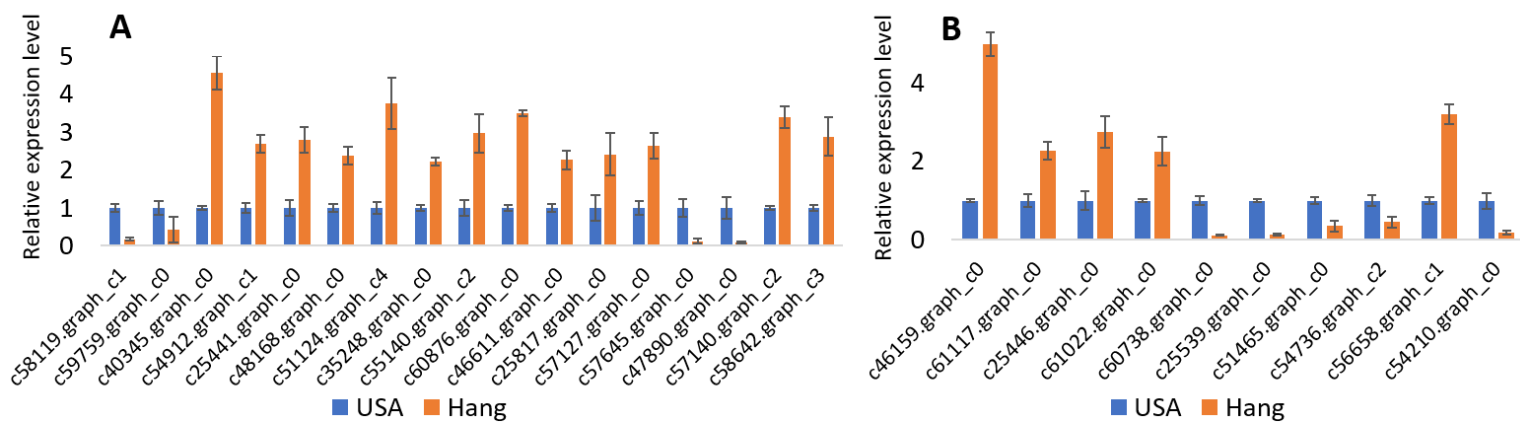

C

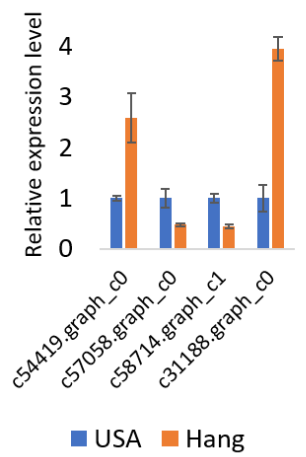

D

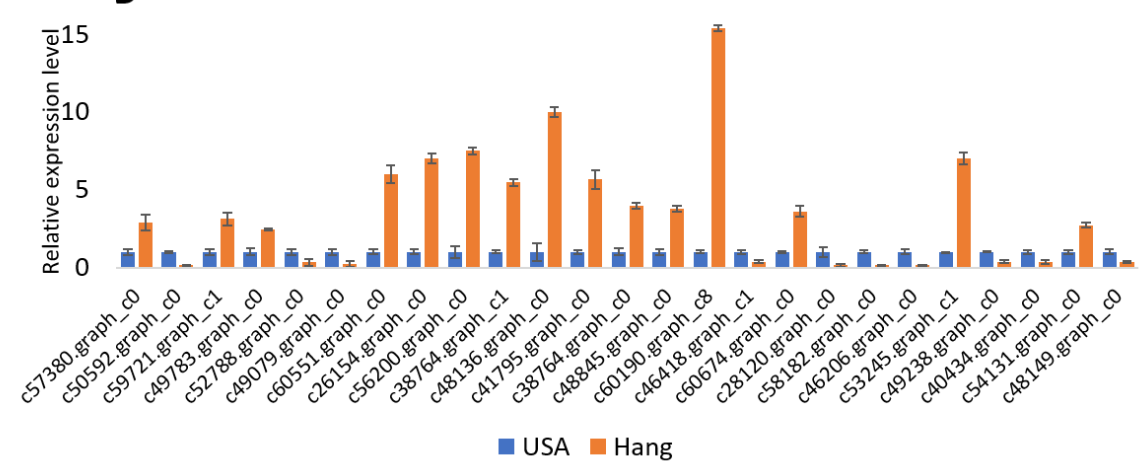

Figure 4. qRT-PCR results of genes related to bottle gourd fruit size. (A) Genes related to cell wall metabolism during fruit development; (B) Genes related to hormones involved in fruit development; (C) Genes controlling cell cycle and cell division during fruit development; (D) Transcription factors regulating fruit size.

\section{Discussion}

Transcriptomic sequencing of two bottle gourd accessions yielded 89,347 Unigenes. A small fraction of these Unigenes showed differential expression for bottle gourd fruit size, which indicates that few genes related to bottle gourd fruit size were expressed at the maturity stage. The mining of differentially expressed genes (DEGs) related to fruit size could be improved by sampling at early growth stages of bottle gourd fruit, and this is the objective of an ongoing study.

Fruit growth is a result of rapid cell division and cell elongation until the fruit gains its maximum size and starts ripening [40]. Cyclins are well known for regulating cell cycle [51]. The cell cycle is regulated at two points, G1/S and G2/M transition phases [52]. Cyclins, along with cyclin-dependent kinases, regulate cell cycle at these two checkpoints by phosphorylation of excessive substrate, thus starting DNA replication and mitosis [53]. We identified three cyclin genes showing significantly higher expression in the big size fruits of Hang cultivar. c58714.graph_c1 encodes G2/mitotic-specific cyclin-1, which is essential for the regulation of the G2/M phase transition in mitosis [54]. c54419.graph_c0 encodes Cyclin-D4-1, which is involved in the G1/S phase transition during cell division [55]. Higher expression levels of these cyclin genes in Hang fruits suggest their positive role in fruit size determination.

The modification of the plant cell wall is highly required for the release of wall stress and a decrease in rigidity to allow cell elongation. Expansins are known for the modification of the cell wall during the growth stage. Expansins cause extension in the cell wall by disrupting the non-covalent bond between cell wall microfibrils and glucan matrix [56]. Plant tissues under rapid growth are supposed to have a higher level of expansin gene expression [57]. Our findings supported this idea. Four expansin genes showing significant differential expression were identified. All of these genes were highly upregulated in Hang fruits, which suggests that these genes could be important candidates for increasing bottle gourd fruit size. Further validation and characterization of these genes can be done by transgenic approaches. Endoglucanases are involved in endohydrolysis of (1->4)- $\beta$-D-glucosidic linkages in cellulose and contribute to cellulose microfibril formation and cell 
wall organization during elongation. Six DEGs related to endoglucanase were identified. Five of these were upregulated in Hang fruits. Xyloglucans are an essential component of the cell wall. Xyloglucan endotransglucosylase/hydrolases (XTH) cleaves and relegates xyloglucan polymers and participates in cell wall construction in growing tissues. Four XTH genes were differentially regulated in the two cultivars, including up- and downregulated genes. Recently, Han et al. [58] found that two members DkXTH6 and DkXTH7 of the XTH family, have opposite expression patterns and play special and divergent roles in persimmon fruit. While one takes part in cell wall restructuring, the other is involved in cell wall assembly. In this study, differential expression of cell wall modification-related genes between the two bottle gourd cultivars suggests their active role in regulating the fruit size in bottle gourd. Further investigations will be required to elucidate the specific function of each DEG and their impact on fruit size.

Hormones also contribute to the regulation of fruit development. Cytokinin accelerates cell division during the growth stage [59]. Cytokinin dehydrogenase (CKX) breaks down the cytokinin [60]. Overexpression of cytokinin dehydrogenase in Arabidopsis led to alterations in plant growth [61]. Two CKX genes were downregulated in Hang fruits suggesting that these genes negatively regulate fruit size. The role of auxin in plant cell expansion is well established [20]. Many studies have demonstrated the role of auxin response factors (ARFs), the main regulators of auxin, in cell division and plant growth [21,23,24,62]. We identified eight auxin-related genes showing significant differential expression among the two cultivars. These genes represent important resources to be further characterized to uncover their specific roles in the regulation of fruit size in bottle gourd.

Although several studies were conducted to identify quantitative trait loci related to fruit size and shape in bottle gourd [63], no putative gene has been specifically reported so far. Well characterized genes related to fruit size were identified in other plants, such as tomato and Arabidopsis. Based on our transcriptome assembly, we successfully identified several homologs in bottle gourd. Fruit weight 2.2 is a negative regulator of cell division and determines fruit size in tomato [48]. In our study, the expression of the homologous gene was significantly repressed in Hang. In accordance with the notion that Cell Size Regulator (CSR) positively controls cell size and fruit weight, we observed an upregulation of CSR in Hang [49]. Furthermore, AtHXK-1 activity has been shown to perturb carbon and energy metabolism and reduce fruit and seed size in tomato [50]. The homologous gene found within our DEGs showed an upregulation in the small-size fruits of USA. Therefore, we deduce that the molecular mechanisms related to fruit size in other well studied plants may be conserved in bottle gourd, and the homology-based candidate gene mining could be an efficient way to pinpoint important gene resources [64].

Regulation of the expression levels of structural genes is under the tight control of transcription factor (TF) [8]. In this study, the upregulation of several ERFs in Hang fruit denotes that they positively contribute to the big fruit size. Numerous studies identified ERF genes as master regulators of the expression levels of phytohormones, cell wall modification, cell cycle, and other important structural genes involved in fruit development and ripening [65-67]. Decoding the networks connecting ERFs and other TFs identified in the present work to their target structural genes will highlight the most important genes to target for efficient fruit size manipulation in bottle gourd [68].

\section{Conclusions}

We performed RNA-seq of two bottle gourd accessions to study the genes controlling the fruit size. Although mature fruits were used in this study, we successfully identified several candidate genes related to cell wall metabolism, phytohormones, cell division, cell cycle regulation, and transcription factors that probably regulate fruit size in bottle gourd. Sampling at different time points during fruit growth will provide a better insight into the molecular mechanisms of bottle gourd fruit development and size. Overall, our study provides a basis for further investigation of the molecular regulation of fruit growth and size in bottle gourd. 
Supplementary Materials: The following are available online at http://www.mdpi.com/2073-4425/11/4/359/s1, Table S1: Primer list of genes selected for qRT-PCR; Table S2. List of the differentially expressed genes between Hang and USA fruits; Figure S1. Unigene length distribution.

Author Contributions: H.Z. and X.C. designed the study. X.C. supervized the work and revized the manuscript. H.Z., J.T., M.Z., and S.H. carried out the experiment, data analysis, interpretation of the results. H.Z. drafted the manuscript. All authors have read and agreed to the published version of the manuscript'.

Funding: This work was financially supported by the National Natural Science Foundation of China (31701936) and the subproject of the National Key Research and Development Program of China (2017YFD0101904).

Conflicts of Interest: The authors declare no conflict of interest.

\section{References}

1. Wu, S.; Shamimuzzaman, M.D.; Sun, H.; Salse, J.; Sui, X.; Wilder, A.; Wu, Z.; Levi, A.; Xu, Y.; Ling, K.-S.; et al. The bottle gourd genome provides insights into Cucurbitaceae evolution and facilitates mapping of a papaya ring-spot virus resistance locus. Plant J. 2017, 92, 963-975. [CrossRef] [PubMed]

2. Roopan, S.M.; Rajeswari, D.; Kalpana, V.N.; Elango, G. Biotechnology and pharmacological evaluation of Indian vegetable crop Lagenaria siceraria: An overview. Appl. Microbiol. Biotechnol. 2015, 100, 1153-1162. [CrossRef] [PubMed]

3. Renner, S.S.; Schäfer, H. Phylogeny and Evolution of the Cucurbitaceae. In Comparative and Evolutionary Genomics of Angiosperm Trees; Springer Science and Business Media LLC: Berlin, Germany, 2016; Volume 20, pp. 13-23.

4. Paulino, E.T.; Ferreira, A.K.B.; Da Silva, J.C.G.; Costa, C.D.F.; Smaniotto, S.; De Araújo-Júnior, J.X.; Júnior, E.F.S.; Bortoluzzi, J.; Ribeiro, Ê.A.N. Cardioprotective effects induced by hydroalcoholic extract of leaves of Alpinia zerumbet on myocardial infarction in rats. J. Ethnopharmacol. 2019, 242, 112037. [CrossRef] [PubMed]

5. Schaffer, A.; Paris, H. Melons, Squashes, and Gourds. In Reference Module in Food Science; Elsevier BV: Amsterdam, The Netherlands, 2016.

6. Quamruzzaman, A.; Rahman, M.; Akter, L. Performance of Bottle Gourd Lines in Bangladesh Condition. Ann. Boil. Sci. 2017, 5, 01. [CrossRef]

7. Seymour, G.B.; Østergaard, L.; Chapman, N.; Knapp, S.; Martin, C. Fruit Development and Ripening. Annu. Rev. Plant Boil. 2013, 64, 219-241. [CrossRef]

8. Karlova, R.; Chapman, N.; David, K.; Angenent, G.C.; Seymour, G.B.; De Maagd, R.A. Transcriptional control of fleshy fruit development and ripening. J. Exp. Bot. 2014, 65, 4527-4541. [CrossRef]

9. Renaudin, J.-P.; Deluche, C.; Cheniclet, C.; Chevalier, C.; Frangne, N. Cell layer-specific patterns of cell division and cell expansion during fruit set and fruit growth in tomato pericarp. J. Exp. Bot. 2017, 68, 1613-1623. [CrossRef]

10. Cosgrove, D.J. Growth of the plant cell wall. Nat. Rev. Mol. Cell Boil. 2005, 6, 850-861. [CrossRef]

11. Bashline, L.; Lei, L.; Li, S.; Gu, Y. Cell Wall, Cytoskeleton, and Cell Expansion in Higher Plants. Mol. Plant 2014, 7, 586-600. [CrossRef]

12. Forlani, S.; Masiero, S.; Mizzotti, C. Fruit ripening: The role of hormones, cell wall modifications, and their relationship with pathogens. J. Exp. Bot. 2019, 70, 2993-3006. [CrossRef]

13. Harmer, S.; Orford, S.; Timmis, J.; S., H.; S., O.; J., T. Characterisation of six $\alpha$-expansin genes in Gossypium hirsutum (upland cotton). Mol. Genet. Genom. 2002, 268, 1-9. [CrossRef] [PubMed]

14. Ando, K.; Carr, K.M.; Grumet, R. Transcriptome analyses of early cucumber fruit growth identifies distinct gene modules associated with phases of development. BMC Genom. 2012, 13, 518. [CrossRef] [PubMed]

15. Jiang, L.; Yan, S.; Yang, W.; Li, Y.; Xia, M.; Chen, Z.; Wang, Q.; Yan, L.; Song, X.; Liu, R.; et al. Transcriptomic analysis reveals the roles of microtubule-related genes and transcription factors in fruit length regulation in cucumber (Cucumis sativus L.). Sci. Rep. 2015, 5, 8031. [CrossRef] [PubMed]

16. Joubes, J.; Phan, T.-H.; Just, D.; Rothan, C.; Bergounioux, C.; Raymond, P.; Chevalier, C. Molecular and Biochemical Characterization of the Involvement of Cyclin-Dependent Kinase A during the Early Development of Tomato Fruit. Plant Physiol. 1999, 121, 857-869. [CrossRef]

17. Joubes, J.; Walsh, D.; Raymond, P.; Chevalier, C. Molecular characterization of the expression of distinct classes of cyclins during the early development of tomato fruit. Planta 2000, 211, 430-439. [CrossRef] 
18. Kumar, R.; Khurana, A.; Sharma, A. Role of plant hormones and their interplay in development and ripening of fleshy fruits. J. Exp. Bot. 2013, 65, 4561-4575. [CrossRef]

19. Matsuo, S.; Kikuchi, K.; Fukuda, M.; Honda, I.; Imanishi, S. Roles and regulation of cytokinins in tomato fruit development. J. Exp. Bot. 2012, 63, 5569-5579. [CrossRef]

20. Pattison, R.; Csukasi, F.; Catalá, C. Mechanisms regulating auxin action during fruit development. Physiol. Plant. 2014, 151, 62-72. [CrossRef]

21. Yuan, Y.; Xu, X.; Gong, Z.; Tang, Y.; Wu, M.; Yan, F.; Zhang, X.; Zhang, Q.; Yang, F.; Hu, X.; et al. Auxin response factor $6 \mathrm{~A}$ regulates photosynthesis, sugar accumulation, and fruit development in tomato. Hortic. Res. 2019, 6, 85-116. [CrossRef]

22. Kumar, R.; Tyagi, A.K.; Sharma, A. Genome-wide analysis of auxin response factor (ARF) gene family from tomato and analysis of their role in flower and fruit development. Mol. Genet. Genom. 2011, 285, 245-260. [CrossRef]

23. Guilfoyle, T.J.; Hagen, G. Auxin response factors. Curr. Opin. Plant Boil. 2007, 10, 453-460. [CrossRef]

24. Zhang, Y.; Zeng, Z.; Chen, C.; Li, C.; Xia, R.; Li, J. Genome-wide characterization of the auxin response factor (ARF) gene family of litchi (Litchi chinensis Sonn.): Phylogenetic analysis, miRNA regulation and expression changes during fruit abscission. PeerJ 2019, 7, e6677. [CrossRef]

25. Zhang, Z.; Li, X. Genome-wide identification of AP2/ERF superfamily genes and their expression during fruit ripening of Chinese jujube. Sci. Rep. 2018, 8, 15612. [CrossRef]

26. Wang, X.; Zeng, W.; Ding, Y.; Wang, Y.; Niu, L.; Yao, J.-L.; Pan, L.; Lu, Z.; Cui, G.; Li, G.; et al. Peach ethylene response factor PpeERF2 represses the expression of ABA biosynthesis and cell wall degradation genes during fruit ripening. Plant Sci. 2019, 283, 116-126. [CrossRef]

27. Shin, A.Y.; Kim, Y.M.; Koo, N.; Lee, S.M.; Nahm, S.; Kwon, S.Y. Transcriptome analysis of the oriental melon (Cucumis melo L. var. makuwa) during fruit development. PeerJ 2017, 5, e2834. [CrossRef]

28. Zhang, H.; Wang, H.; Yi, H.; Zhai, W.; Wang, G.; Fu, Q. Transcriptome profiling of Cucumis melo fruit development and ripening. Hortic. Res. 2016, 3, 16014. [CrossRef]

29. Xu, X.; Pan, J.; He, M.; Tian, H.; Qi, X.; Xu, Q.; Chen, X. Transcriptome profiling reveals key genes related to astringency during cucumber fruit development. 3 Biotech 2019, 9, 390. [CrossRef]

30. D’Esposito, D.; Ferriello, F.; Molin, A.D.; Diretto, G.; Sacco, A.; Minio, A.; Barone, A.; Di Monaco, R.; Cavella, S.; Tardella, L.; et al. Unraveling the complexity of transcriptomic, metabolomic and quality environmental response of tomato fruit. BMC Plant Boil. 2017, 17, 66. [CrossRef]

31. Shinozaki, Y.; Nicolas, P.; Fernandez-Pozo, N.; Ma, Q.; Evanich, D.J.; Shi, Y.; Xu, Y.; Zheng, Y.; Snyder, S.I.; Martin, L.B.B.; et al. High-resolution spatiotemporal transcriptome mapping of tomato fruit development and ripening. Nat. Commun. 2018, 9, 364. [CrossRef]

32. Qi, J.; Liu, X.; Shen, D.; Miao, H.; Xie, B.; Li, X.; Zeng, P.; Wang, S.; Shang, Y.; Gu, X.; et al. A genomic variation map provides insights into the genetic basis of cucumber domestication and diversity. Nat. Genet. 2013, 45, 1510-1515. [CrossRef]

33. Wang, L.; Cao, C.; Zheng, S.; Zhang, H.; Liu, P.; Ge, Q.; Li, J.; Ren, Z. Transcriptomic analysis of short-fruit 1 (sf1) reveals new insights into the variation of fruit-related traits in Cucumis sativus. Sci. Rep. 2017, 7, 2950. [CrossRef]

34. Grabherr, M.G.; Haas, B.J.; Yassour, M.; Levin, J.; Thompson, D.A.; Amit, I.; Adiconis, X.; Fan, L.; Raychowdhury, R.; Zeng, Q.; et al. Full-length transcriptome assembly from RNA-Seq data without a reference genome. Nat. Biotechnol. 2011, 29, 644-652. [CrossRef]

35. Li, B.; Dewey, C.N. RSEM: Accurate transcript quantification from RNA-Seq data with or without a reference genome. BMC Bioinform. 2011, 12, 323. [CrossRef]

36. Wang, L.; Feng, Z.; Zhang, X. DEGseq: An R package for identifying differentially expressed genes from RNA-seq data. Bioinform. 2009, 26, 136-138. [CrossRef]

37. Storey, J.D.; Tibshirani, R. Statistical significance for genome wide studies. Proc. Natl. Acad. Sci. USA 2003, 100, 9440-9445. [CrossRef]

38. Xie, C.; Mao, X.; Huang, J.; Ding, Y.; Wu, J.; Dong, S.; Kong, L.; Gao, G.; Li, C.-Y.; Wei, L. KOBAS 2.0: A web server for annotation and identification of enriched pathways and diseases. Nucleic Acids Res. 2011, 39, W316-W322. [CrossRef] 
39. Zhang, C.; Zheng, H.; Wu, X.; Xu, H.; Han, K.; Peng, J.; Lu, Y.; Lin, L.; Xu, P.; Wu, X.; et al. Genome-wide identification of new reference genes for RT-qPCR normalization in CGMMV-infected Lagenaria siceraria. PeerJ 2018, 6, e5642. [CrossRef]

40. Anwar, R.; Fatima, S.; Mattoo, A.K.; Handa, A. Fruit Architecture in Polyamine-Rich Tomato Germplasm Is Determined via a Medley of Cell Cycle, Cell Expansion, and Fruit Shape Genes. Plants 2019, 8, 387. [CrossRef]

41. Ban, Q.; Han, Y.; He, Y.; Jin, M.; Han, S.; Suo, J.; Rao, J. Functional characterization of persimmon beta-galactosidase gene DkGAL1 in tomato reveals cell wall modification related to fruit ripening and radicle elongation. Plant Sci. 2018, 274, 109-120. [CrossRef]

42. Tenhaken, R. Cell wall remodeling under abiotic stress. Front. Plant Sci. 2015, 5, 771. [CrossRef]

43. Lee, J.; Burns, T.H.; Light, G.; Sun, Y.; Fokar, M.; Kasukabe, Y.; Fujisawa, K.; Maekawa, Y.; Allen, R.D. Xyloglucan endotransglycosylase/hydrolase genes in cotton and their role in fiber elongation. Planta 2010, 232, 1191-1205. [CrossRef]

44. Quoc, N.B.; Chau, N.N.B. The Role of Cell Wall Degrading Enzymes in Pathogenesis of Magnaporthe oryzae. Curr. Protein Pept. Sci. 2017, 18, 1. [CrossRef]

45. Su, L.; Bassa, C.; Audran, C.; Mila, I.; Cheniclet, C.; Chevalier, C.; Bouzayen, M.; Roustan, J.-P.; Chervin, C. The Auxin Sl-IAA17 Transcriptional Repressor Controls Fruit Size Via the Regulation of Endoreduplication-Related Cell Expansion. Plant Cell Physiol. 2014, 55, 1969-1976. [CrossRef]

46. Bartrina, I.; Otto, E.; Strnad, M.; Werner, T.; Schmülling, T. Cytokinin Regulates the Activity of Reproductive Meristems, Flower Organ Size, Ovule Formation, and Thus Seed Yield in Arabidopsis thaliana[C][W][OA]. Plant Cell 2011, 23, 69-80. [CrossRef]

47. Rieu, I.; Ruiz-Rivero, O.; Fernandez-Garcia, N.; Griffiths, J.; Powers, S.J.; Gong, F.; Linhartova, T.; Eriksson, S.; Nilsson, O.; Thomas, S.G.; et al. The gibberellin biosynthetic genes AtGA20ox1 and AtGA20ox2 act, partially redundantly, to promote growth and development throughout the Arabidopsis life cycle. Plant J. 2007, 53, 488-504. [CrossRef]

48. Frary, A.; Nesbitt, T.C.; Grandillo, S.; Van Der Knaap, E.; Cong, B.; Liu, J.; Meller, J.; Elber, R.; Alpert, K.B.; Tanksley, S.D. fw2.2: A Quantitative Trait Locus Key to the Evolution of Tomato Fruit Size. Science 2000, 289, 85-88. [CrossRef]

49. Mu, Q.; Huang, Z.; Chakrabarti, M.; Illa-Berenguer, E.; Liu, X.; Wang, Y.; Ramos, A.; Van Der Knaap, E. Fruit weight is controlled by Cell Size Regulator encoding a novel protein that is expressed in maturing tomato fruits. PLoS Genet. 2017, 13, e1006930. [CrossRef]

50. Menu, T.; Saglio, P.; Granot, D.; Dai, N.; Raymond, P.; Ricard, B. High hexokinase activity in tomato fruit perturbs carbon and energy metabolism and reduces fruit and seed size. Plant Cell Environ. 2004, 27, 89-98. [CrossRef]

51. Bendris, N.; Lemmers, B.; Blanchard, J.M. Cell cycle, cytoskeleton dynamics and beyond: The many functions of cyclins and CDK inhibitors. Cell Cycle 2015, 14, 1786-1798. [CrossRef]

52. Barnum, K.J.; O'Connell, M.J. Cell cycle regulation by checkpoints. Breast Cancer 2014, 1170, $29-40$.

53. Malumbres, M. Cyclin-dependent kinases. Genome Biol. 2014, 15, 122. [CrossRef] [PubMed]

54. Li, W.; Zhang, L.; Ding, Z.; Wang, G.; Zhang, Y.; Gong, H.; Chang, T.; Zhang, Y. De novo sequencing and comparative transcriptome analysis of the male and hermaphroditic flowers provide insights into the regulation of flower formation in andromonoecious taihangia rupestris. BMC Plant Boil. 2017, $17,54$. [CrossRef] [PubMed]

55. Liu, Y.; Hu, H.; Li, Z. The cooperative roles of PHO80-like cyclins in regulating the G1/S transition and posterior cytoskeletal morphogenesis in Trypanosoma brucei. Mol. Microbiol. 2013, 90, 130-146. [PubMed]

56. Cosgrove, D.J. Plant expansins: Diversity and interactions with plant cell walls. Curr. Opin. Plant Boil. 2015, 25, 162-172. [CrossRef]

57. Marowa, P.; Ding, A.; Kong, Y. Expansins: Roles in plant growth and potential applications in crop improvement. Plant Cell Rep. 2016, 35, 949-965. [CrossRef]

58. Han, Y.; Ban, Q.; Hou, Y.; Meng, K.; Suo, J.; Rao, J. Isolation and Characterization of Two Persimmon Xyloglucan Endotransglycosylase/Hydrolase (XTH) Genes That Have Divergent Functions in Cell Wall Modification and Fruit Postharvest Softening. Front. Plant Sci. 2016, 7, 149. [CrossRef]

59. Kieber, J.J.; Schaller, G.E. Cytokinins. Arabidopsis Book/Am. Soc. Plant Biol. 2014, 12, e0168-e. [CrossRef] 
60. Reid, D.E.; Heckmann, A.B.; Novák, O.; Kelly, S.; Stougaard, J. CYTOKININ OXIDASE/DEHYDROGENASE3 Maintains Cytokinin Homeostasis during Root and Nodule Development in Lotus japonicus. Plant Physiol. 2015, 170, 1060-1074. [CrossRef]

61. Köllmer, I.; Novák, O.; Strnad, M.; Schmülling, T.; Werner, T. Overexpression of the cytosolic cytokinin oxidase/dehydrogenase (CKX7) from Arabidopsis causes specific changes in root growth and xylem differentiation. Plant J. 2014, 78, 359-371. [CrossRef]

62. Yuan, Y.; Mei, L.; Wu, M.; Wei, W.; Shan, W.; Gong, Z.; Zhang, Q.; Yang, F.; Yan, F.; Zhang, Q.; et al. SlARF10, an auxin response factor, is involved in chlorophyll and sugar accumulation during tomato fruit development. J. Exp. Bot. 2018, 69, 5507-5518. [CrossRef]

63. Wang, Y.; Xu, P.; Wu, X.; Wu, X.; Wang, B.; Huang, Y.; Hu, Y.; Lin, J.; Lu, Z.; Li, G. GourdBase: A genomecentered multi-omics database for the bottle gourd (Lagenaria siceraria), an economically important cucurbit crop. Sci. Rep. 2018, 8, 3604. [CrossRef] [PubMed]

64. Dossa, K.; Mareme, N.; Achille, E.A.; Ndiaga, C.; Diaga, D.; Zhang, X.; Niang, M.; Assogbadjo, A.E.; Cisse, N.; Diouf, D. Whole genome homology-based identification of candidate genes for drought tolerance in sesame (Sesamum indicum L.). Afr. J. Biotechnol. 2016, 15, 1464-1475.

65. Merchante, C.; Alonso, J.M.; Stepanova, A.N. Ethylene signaling: Simple ligand, complex regulation. Curr. Opin. Plant Boil. 2013, 16, 554-560. [CrossRef] [PubMed]

66. Jung, J.; Choi, S.C.; Jung, S.; Cho, B.-K.; Ahn, G.-H.; Ryu, S.I. A Transcriptome Approach toward Understanding Fruit Softening in Persimmon. Front. Plant Sci. 2017, 8, 1556. [CrossRef]

67. Alexander, L.; Grierson, D. Ethylene biosynthesis and action in tomato: A model for climacteric fruit ripening. J. Exp. Bot. 2002, 53, 2039-2055. [CrossRef]

68. Zhang, X.; Mmadi, M.A.; Zhou, R.; Zhang, T.; Su, R.; Zhang, Y.; Wang, L.; You, J.; Zhang, X. Depicting the Core Transcriptome Modulating Multiple Abiotic Stresses Responses in Sesame (Sesamum indicum L.). Int. J. Mol. Sci. 2019, 20, 3930.

(C) 2020 by the authors. Licensee MDPI, Basel, Switzerland. This article is an open access article distributed under the terms and conditions of the Creative Commons Attribution (CC BY) license (http://creativecommons.org/licenses/by/4.0/). 